\title{
PREPARATION AND CHARACTERIZATION OF MOLECULAR IMPRINTED POLYMER FOR THE SELECTIVE RECOGNITION OF SEROTONIN
}

\author{
Ceylan Hepokur ${ }^{1,}$, H. Nursevin $\ddot{O}_{z t o p}{ }^{1}$, Dursun Saraydin ${ }^{1}$
}

https://doi.org/10.23939/chcht14.02.195

\begin{abstract}
Molecularly imprinted polymers (MIPs) were prepared for highly selective recognition of serotonin. Acrylamide, methacrylic acid and methacrylamide were selected as the monomers for the production of MIPs. Functional monomers were polymerized with ethylene glycol dimethacrylate, 1,4-butanediol diacrylate, and trimethylpropane triacrylate with serotonin (MIP-EGDMA, MIP-BUT and MIP-TMT). Serotonin was removed from MIP by the mixture of methanol/acetic acid (4:1). Nonimprinted polymers (NIPs) were synthesized without serotonin (NIP-EGDMA, NIP-BUT and NIP-TMT). For the characterization of synthesized polymers FTIR, DSC, TGA, and SEM analysis were investigated. The parameters that affect the adsorption of serotonin on polymers such as temperature, $\mathrm{pH}$ and concentration were evaluated. The selectivity and reusability studies were also investigated.
\end{abstract}

Keywords: acrylamide, methacrylic acid, methacrylamide, molecularly imprinted polymers, serotonin.

\section{Introduction}

Some of the most important amines derived from amino acids are found in the nervous system [1]. Most of them are known as neurotransmitters. Nerves transmit an impulse from one side of the body to another side through moving ion waves. When the wave reaches the end of the neuron, it triggers the release of a transmitter. When the transmitter reaches another cell, it causes the formation of another wave there. Serotonin is a monoamine transmitter having a high biological significance. In spite of the simple structure of serotonin, it is known that it plays an active role in cardiovascular system, central nervous system, blood platelets and gastrointestinal system [2]. Serotonin is an indoleamine, which was first purified from the blood by Page and coworkers in 1948 and its chemistry was revealed a year later. Serotonin is present in a variety of plant and animal tissues, in snake's venom,

\footnotetext{
${ }^{1}$ Sivas Cumhuriyet University, Sivas, Turkey

cozsoya@gmail.com

(C) Hepokur C., Oztop N., Saraydin D., 2020
}

in the needle of bee and scorpion, etc. [3, 4]. Serotonin (5hydroxytryptamine, 5-HT), which is synthesized from Ltryptophan (an essential amino acid) is a smooth muscle stimulant and a vasoconstrictor.

Molecular imprint is a technique developed for the preparation of the polymers allowing a high affinity for the target molecule. Molecularly imprinted polymers (MIPs) behave selectively towards the target molecule. Particular bonding areas are shaped with the functional groups of the template and polymerization occurs with the monomer and cross-linker. As a result, selective areas are formed in molecularly imprinted polymers. After the polymerization, the template is removed from the polymer; complementary cavities have the ability to recognize the size, shape, and function of the template [5-10]. The differences occurred in the binding areas of the imprinted polymers are due to the impact of the temperature used in the imprinting process. Many researchers prefer $333 \mathrm{~K}$ as the polymerization temperature. However, the onset of polymerization is very fast and it is difficult to control the temperature. Selecting a low temperature and an extended reaction time allows for more repeatable polymerization [11-18].

This study intends the preparation, characterization and using of serotonin imprinted polymers in serotonin adsorption. Acrylamide-methacrylamide-methacrylic acid monomers are selected for the polymer preparation. These monomers are polymerized with the target molecule in the presence of cross-linkers. After the polymerization process, serotonin is removed from MIP. MIPs are prepared for each target molecule and used in adsorption studies. In addition, MIP samples are compared with non-imprinted polymers (NIPs).

\section{Experimental}

\subsection{Materials}

Serotonin (Ser) was obtained from Alfa Aesar (Karlsruhe, Germany). Acrylamide (AAm), metacrylamide (MAN), methacrylic acid (MAA), ethylene glycol dimethacrylate (EGDMA), methanol $(\mathrm{MeOH})$, acetic acid 
(AcA), sodium dihydrogen phosphate, disodium hydrogen phosphate, sodium chloride, 1,4-butanediol diacrylate (BUT) were obtained from Merck (Darmstadt, Germany). $\alpha$ - $\alpha$-Azobisisobutyronitrile (AIBN) was obtained from Fluka (Chemie AG CH-9470 Buchs). Dimethyl sulfoxide (DMSO) was obtained from Carlo Erba (Rohano, Italy). Tween 20, Triton X 100 were purchased from Ambresco (Solon,Ohio).

\subsection{Preparation of MIPs and NIPs}

Before preparation of serotonin imprinted polymers, serotonin, monomers, a cross-linker and initiator were dissolved in various solvents to find the appropriate one. For this purpose, methanol, ethanol, chloroform, toluene, dimethylsulfoxide, acetone, $n$-hexane and acetonitrile were used. Serotonin and monomers (acrylamide, metacrylamide and methacrylic acid) were soluble in water. Cross-linker and initiator were soluble in methanol. Therefore water and methanol (1:5) were selected as solvents.

MIPs were synthesized as follows: $1 \mathrm{mmol}$ of serotonin, $0.5 \mathrm{mmol}$ of acrylamide, $1 \mathrm{mmol}$ of methacrylamide and $2.5 \mathrm{mmol}$ of methacrylic acid were dissolved in $1 \mathrm{ml}$ of water. Monomers and serotonin were stirred for $30 \mathrm{~min}$ in order to ensure interaction with the target molecule. 20 mmol of cross-linker (EGDMA, TMT, BUT) were dissolved in $5 \mathrm{ml}$ of methanol and stirred for $30 \mathrm{~min}$ to complete the cross-linking. AIBN as an initiator was dissolved and the solution was taken into a $100 \mathrm{ml}$ flask. The solution was degassed and molecular oxygen was removed with a stream of nitrogen for $10 \mathrm{~min}$. The polymerization was completed in a water bath at $333 \mathrm{~K}$ approximately after $4 \mathrm{~h}$. The resultingt rigid polymers were ground to pass through a $35-42 \mathrm{~mm}$ sieve. After the polymers were washed with methanol, they were dried in Petri dishes at room temperature. Compositions of MIPs are given in Table 1. Non-imprinted polymers (NIPs) were prepared using the same procedure without addition of serotonin.

MIP cross-linked with ethylene glycol dimethacrylate (MIP-EGDMA), MIP cross-linked with 1,4-butanedioldiacrylate (MIP-BUT), MIP cross-linked with trimethylolpropanetriacrylate (MIP-TMT), NIP cross-linked with EGDMA (NIP-EGDMA), NIP crosslinked with BUT (NIP-BUT), and NIP cross-linked with TMT (NIP-TMT) were prepared.

\subsection{Removal of Target Molecule from MIPs}

In order to remove serotonin molecule from MIPs the polymers were washed up by the mixture of methanol/acetic acid $(4: 1, \mathrm{v} / \mathrm{v})$ with a magnetic stirrer at $150 \mathrm{rpm}$ for $24 \mathrm{~h}$ and then filtered. This process was repeated four times [19]. To remove the residues the samples were washed again by distilled water under stirring for $24 \mathrm{~h}$. This procedure was performed twice. The same washing process was applied to NIPs. After washing, the polymer was dried in Petri dishes at room temperature. The amount of serotonin which was removed from the polymer was analyzed using UV-VIS spectrophotometer. Serotonin spectrum was recorded in the $200-700 \mathrm{~nm}$ range. The maximum absorbance was observed within $280-310 \mathrm{~nm}$. Absorption measurements in order to avoid interference from other hydroxyindole were performed at $310 \mathrm{~nm}$ [20].

\subsection{Characterization of MIPs and NIPs}

Examination of the thermal behavior of MIPs and NIPs is important for the purpose of using polymers. Therefore, thermogravimetric analysis (TGA) and differential scanning calorimetry (DSC) were applied. MIP and NIP thermogravimetric analysis was performed with a Shimadzu TGA-50 instrument. DSC analysis was carried out using a Shimadzu DSC-50 differential scanning calorimeter.

Infrared spectra of MIPs and NIPs were obtained by using a FTIR spectrophotometer (Perkin Elmer Spectrum 100 FT-IR Pike Gladi brand/EC).

The surface morphology of MIPs and NIPs was investigated by a scanning electron microscopy (Leo EVO 40XVP).

Table 1

The amount of chemicals used for the preparation of MIPs

\begin{tabular}{|c|c|c|c|c|c|c|c|c|}
\hline \multirow{2}{*}{ Polymer } & \multicolumn{7}{|c|}{ The amount of chemicals } \\
\cline { 2 - 9 } & Serotonin, mmol & AAm, mmol & MAN, mmol & MAA, mmol & EGDMA, mmol & BUT, mmol & TMT, mmol & AIBN, mg \\
\hline MIP-1 & 1 & 0.5 & 1 & 2.5 & 20 & - & - & 10 \\
\hline NIP-1 & - & 0.5 & 1 & 2.5 & 20 & - & - & 10 \\
\hline MIP-2 & 1 & 0.5 & 1 & 2.5 & - & 20 & - & 10 \\
\hline NIP-2 & - & 0.5 & 1 & 2.5 & - & 20 & - & 10 \\
\hline MIP-3 & 1 & 0.5 & 1 & 2.5 & - & - & 20 & 10 \\
\hline NIP-3 & - & 0.5 & 1 & 2.5 & - & - & 20 & 10 \\
\hline
\end{tabular}




\subsection{Serotonin Adsorption on MIPs}

For NIPs and serotonin removed MIPs the adsorption was performed and serotonin adsorption time was determined. Adsorption effects of various solvents, $\mathrm{pH}$, temperature, and concentration were investigated. Studies of selectivity and repeatability were performed.

Serotonin concentrations were determined by UVVIS spectrophotometer. The amount of serotonin that was adsorbed by the polymer was calculated using Eq. (1).

$$
Q=\frac{\left(C_{i}-C_{s}\right)}{m} \cdot V \cdot 1000
$$

where $Q$ is an adsorbed amount of serotonin, mg serotonin/g polymer; $C_{i}$ is an initial concentration of the solution, $\mathrm{mg} / \mathrm{l} ; C_{S}$ is a final concentration of the solution, $\mathrm{mg} / \mathrm{l} ; V$ is the solution volume, $\mathrm{ml} ; m$ is the polymer weight, g.

Adsorption kinetics. To analyze the adsorption kinetics MIP-EGDMA serotonin adsorption was performed at $298 \mathrm{~K}$ for $300 \mathrm{~min}$.

The effect of solvents. After MIPs were prepared with various cross-linkers, serotonin was removed. Adsorption studies of MIPs and NIPs were performed. Distilled water, $\mathrm{NaCl}(0.9 \%)$, water:Tween $20(0.1 \%)$, water:Triton X100 (0.1\%), pH 7.4, pH 6, and DMSO solutions were used for binding studies of serotonin. $20 \mathrm{mg}$ of polymer were added to $100 \mathrm{ppm}$ serotonin solution $(20 \mathrm{ml})$. This mixture was incubated for $2 \mathrm{~h}$ at $298 \mathrm{~K}$. The amount of serotonin was measured with UVVIS spectrophotometry.

The effect of $\mathrm{pH}$, temperature and concentration on serotonin adsorption.

$50 \mathrm{ppm}$ serotonin solution was prepared with phosphate buffers of different $\mathrm{pH}(5.5,6,7,7.4,8) .20 \mathrm{mg}$ of polymer were added to the solution, and incubated for $2 \mathrm{~h}$ at $298 \mathrm{~K}$. After this incubation, the amount of adsorbed serotonin was calculated from Eq. (1).

To study the effect of temperature $20 \mathrm{mg}$ of polymer were added to the serotonin solution (50 ppm, $\mathrm{pH}$ 7.4). Serotonin solution at five different temperatures (293, 298, 303, 308 and $313 \mathrm{~K}$ ) was incubated for $2 \mathrm{~h}$. After this incubation, the amount of adsorbed serotonin was calculated from Eq. (1).

To study the effect of concentration $20 \mathrm{mg}$ of polymer was added to the serotonin solution of different concentrations (from 5 to $300 \mathrm{ppm}$ ). The solution was incubated for $2 \mathrm{~h}$ at $298 \mathrm{~K}$. After this period, the amount of serotonin adsorbed was calculated from Eq. (1).

Selectivity and repeatability.

Homovanilic acid and adrenaline were used for the selectivity studies. $20 \mathrm{mg}$ of polymer, homovanilic acid, and adrenaline solutions of $\mathrm{pH} 7.4$ were added to $500 \mathrm{ppm}$ serotonin solution. The mixture was incubated for $2 \mathrm{~h}$ at
298 K. After this period, the amount of adsorbed serotonin was calculated from Eq. (1).

To determine the amount of adsorbed serotonin $1 \mathrm{~g}$ of polymer was added to $500 \mathrm{ppm}$ serotonin solution and the mixture was incubated for $2 \mathrm{~h}$ at $298 \mathrm{~K}$. Desorption of serotonin was analyzed with methanol:acetic acid (4:1, $\mathrm{v} / \mathrm{v})$ mixture. Adsorption-desorption processes were repeated five times. Repeatability (\% RE) was calculated from Eq. (2).

$$
R E=\frac{Q_{s}}{Q_{1}} \cdot 100 \%
$$

where $Q_{s}$ is the amount of serotonin in the end of the adsorption measurements, mg serotonin/g polymer; $Q_{1}$ is the amount of serotonin at the beginning of the adsorption measurements, $\mathrm{mg}$ serotonin/g polymer.

\section{Results and Discussion}

The most suitable solvent for serotonin removal from MIPs was methanol:acetic acid (4:1) mixture. At the end of this process serotonin was removed from MIPs. Thus new polymers without serotonin were obtained (MIP-EGDMA-R, MIP-BUT-R, MIP-TMT-R).

\subsection{Characterization of MIPs and NIPs}

FTIR spectra (Fig. 1) were taken to explain the chemical structure and bonding mechanisms of polymers.

The characteristic bands of the monomers that formed MIP are observed (Figs. 1b, 1c, 1d). The bands typical of $\mathrm{OH}$ are observed within $1200-1500 \mathrm{~cm}^{-1}$ $\left(1452 \mathrm{~cm}^{-1}\right)$; $\mathrm{C}-\mathrm{N}$ band is observed within $900-1300 \mathrm{~cm}^{-1}$ (1248 $\mathrm{cm}^{-1}$ ) and $\mathrm{C}=\mathrm{O}$ band is observed within 1600$1900 \mathrm{~cm}^{-1}\left(1716 \mathrm{~cm}^{-1}\right)$ [21].

It can be seen that the spectrum (Fig. 1a) of serotonin has characteristic bands observed at 3500$3300 \mathrm{~cm}^{-1}$ between $\mathrm{N}-\mathrm{H}$ band of indole ring and ethylene amine band $[22,23]$. The bending vibrations of $\mathrm{N}-\mathrm{H}$ are seen at $3000-3500 \mathrm{~cm}^{-1}$ in MIP spectrum (Fig. 1b). However the $\mathrm{N}-\mathrm{H}$ vibration signals cannot be observed in NIP and washed MIP spectra (Figs. 1c and 1d). These results indicate that serotonin was included in MIP and it was removed by washing.

Examination of the thermal behavior of polymeric materials is important in terms of choosing the polymer according to the intended use and purpose. Thermal analysis of polymers included thermogravimetric analysis (TGA) and differential scanning calorimetry (DSC).

TGA thermograms of polymers are shown in Fig. 2 as a multi-step thermal decomposition reaction. Thermograms of NIPs and washed MIPs were similar, whereas thermograms of MIPs were different. Firstly, the mass loss between 298 and $473 \mathrm{~K}$ occurred due to the loss of weakly bound water. Then, at the temperature of about $373 \mathrm{~K}$ the 
decomposition of pendant $-\mathrm{NH}_{2}$ and $-\mathrm{COOH}$ groups or the main chain breakdown took place. Finally, the mass loss at above $673 \mathrm{~K}$ resulted from the polymer carbonization.

MIPs were showed as two-step thermal decomposition reactions (Fig. 2). The first decomposition of MIP was due to serotonin molecules. Decomposition process occurs between 473 and $673 \mathrm{~K}$ via intra and intermolecular reactions of the carboxyl group [24, 25].
Carboxyl group is separated from the structures at the temperatures above $473 \mathrm{~K}$. This temperature was found to be different when changing cross-linkers $(473 \mathrm{~K}$ for EGDMA, $573 \mathrm{~K}$ for BUT and $623 \mathrm{~K}$ for TMT). These results demonstrated that the best thermal stability is provided by prepared polymer with TMT. Finally, the mass decomposition occurs at the temperatures above $673 \mathrm{~K}$ due to the main chain breakdown.

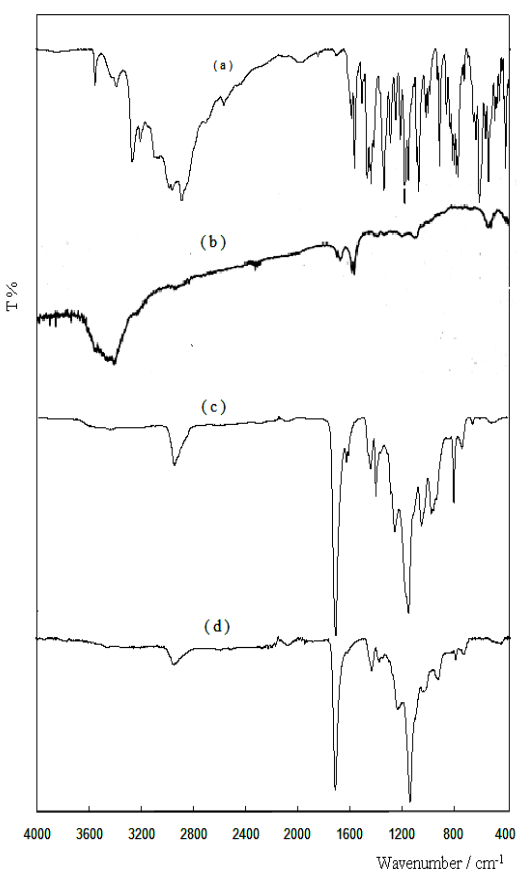

EGDMA

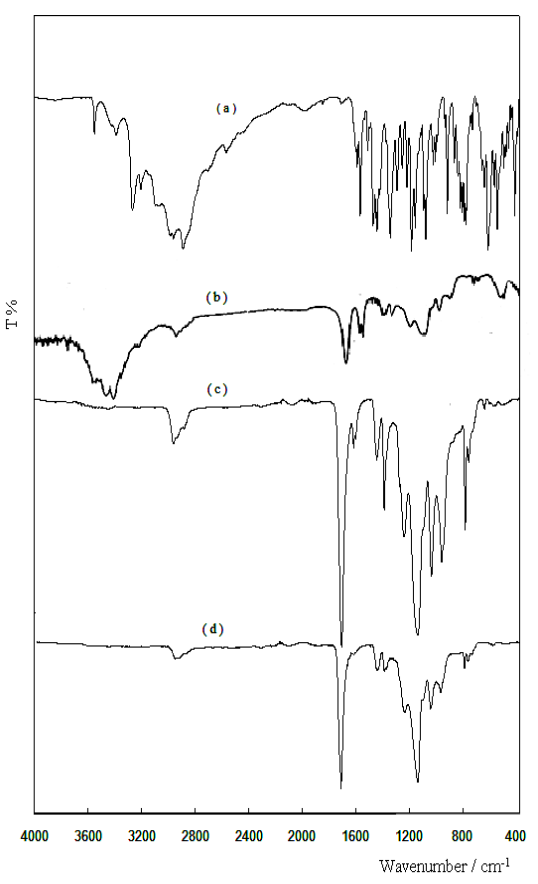

BUT

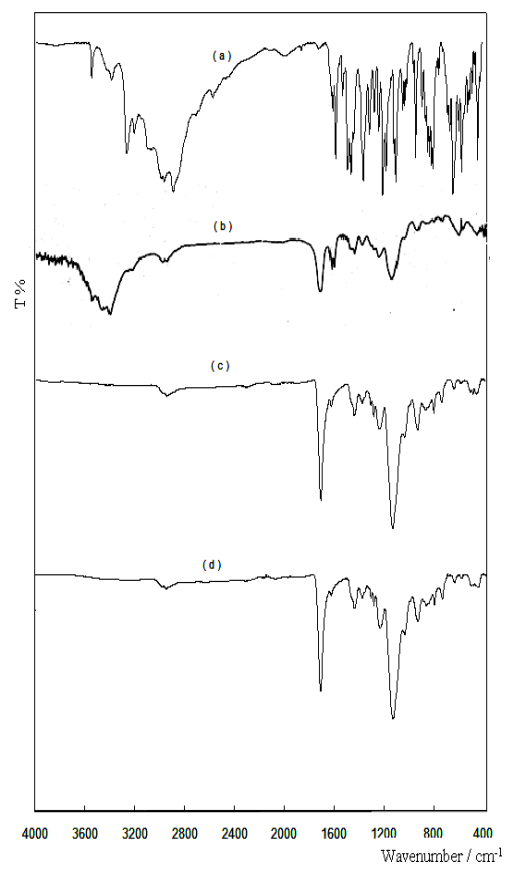

TMT

Fig. 1. FTIR spectra of cross-linked polymers: serotonin (a), MIP (b), NIP (c) and MIP-R (d)

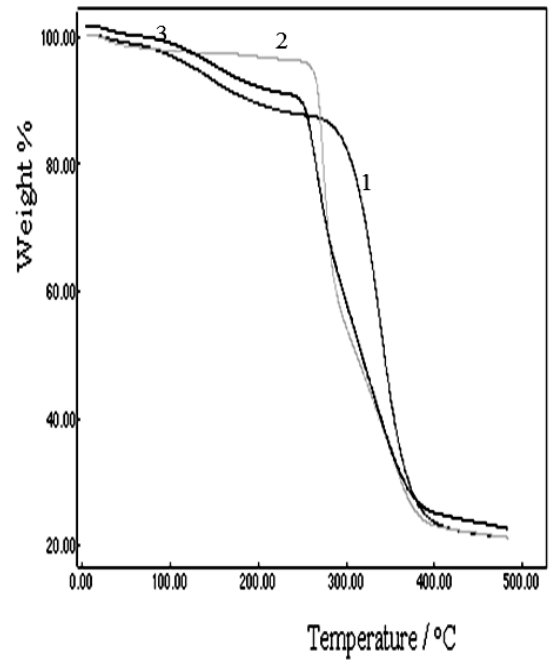

EGDMA

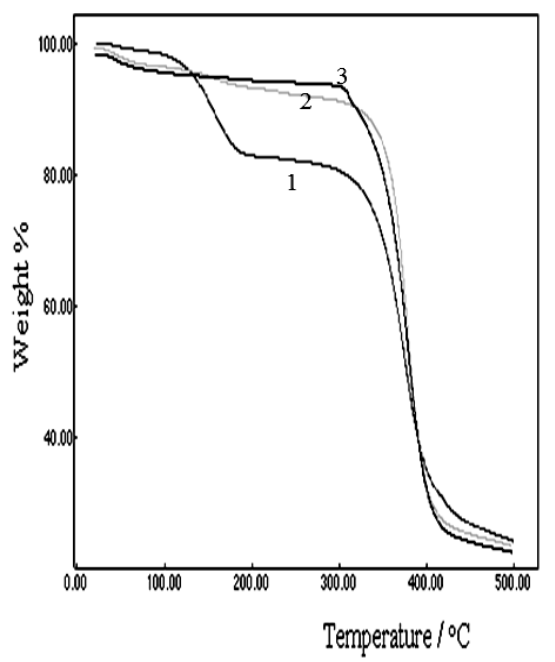

BUT

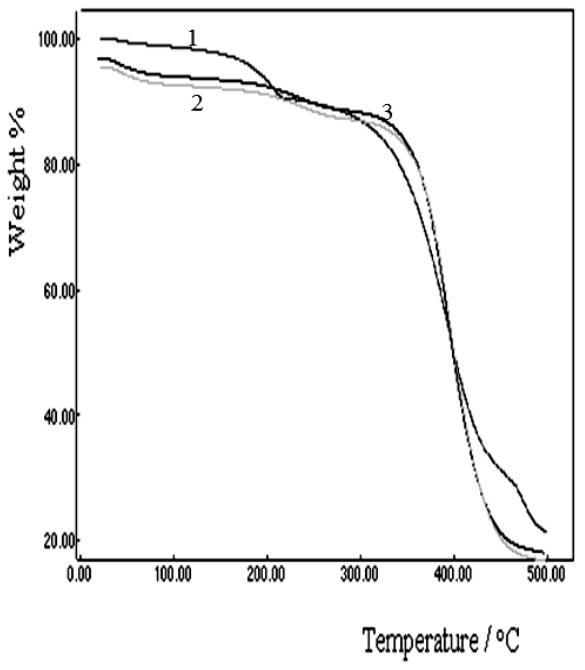

TMT

Fig. 2. TGA thermograms of the cross-linked polymers:

MIP (1), NIP (2), MIP-R (3) 


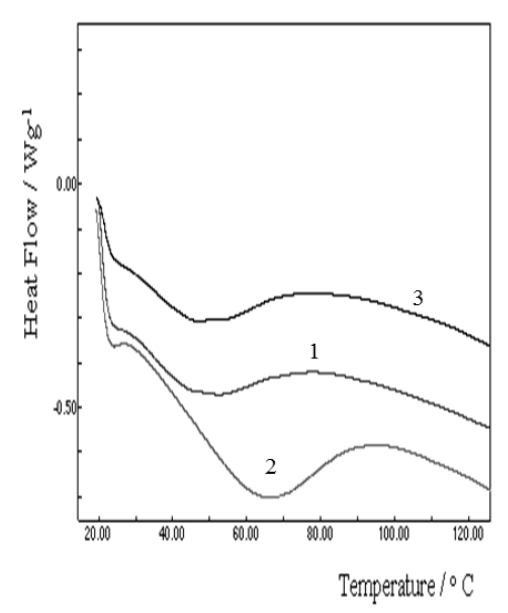

EGDMA

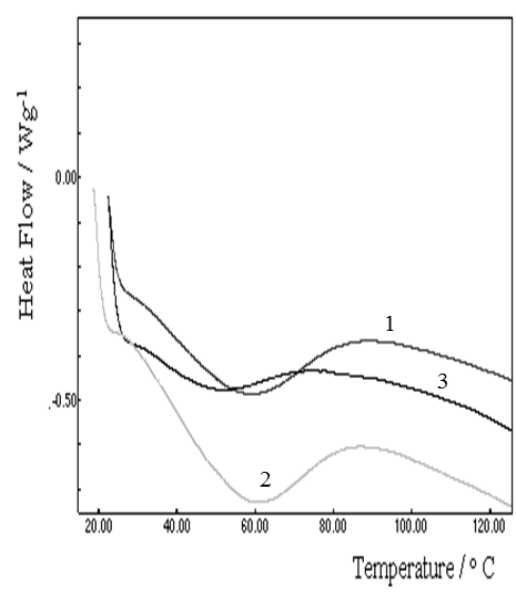

BUT

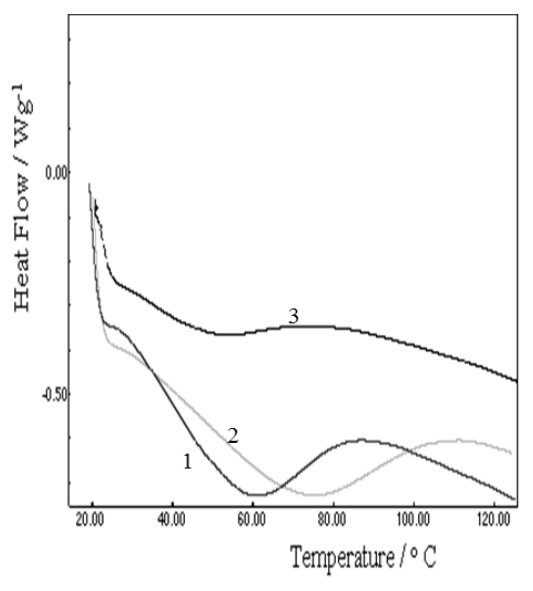

TMT

Fig. 3. The DSC curves of the cross-linked polymers MIP (1), NIP (2), MIP-R (3)

Table 2

The glass transition temperatures of polymers with different cross-linkers

\begin{tabular}{|c|c|c|c|}
\hline \multirow{2}{*}{ Cross-linker } & \multicolumn{3}{|c|}{ Glass transition temperatures for different polymers, K } \\
\cline { 2 - 4 } & MIP NIP & MIP-R \\
\hline EGDMA & 320 & 335 & 320 \\
\hline BUT & 331 & 333 & 322 \\
\hline TMT & 334 & 348 & 327 \\
\hline
\end{tabular}

Glass transition temperatures $\left(T_{g}\right)$ of MIP, washed MIP and NIP were determined by the differential scanning calorimetry (DSC). The DSC curves of the polymers are shown in Fig. 3. The $T_{g}$ values are given in Table 2.

Cross-linking is an important factor for a glass transition temperature. Glass transition temperature of TMT is higher than those of EGDMA and BUT because TMT has a trifunctional group, but EGDMA and BUT have a bifunctional group. The $T_{g}$ value of MIPs is lower than that of NIPs, due to the plasticizing effects of the template molecule. Polymers retain their hard and glassy structures up to $333 \mathrm{~K}$.

SEM images of the polymers prepared with three different cross-linkers are shown in Figs. 4-6. A significant difference between NIPs and MIPs is observed. It is obvious that after the molecular imprinting process MIPs have gaps in a standard size and homogeneous distribution according to NIPs. Change of cross-linkers also caused apparent differences in MIP morphology.

\subsection{Serotonin Adsorption}

Serotonin adsorption was performed on NIP and serotonin removed MIP samples. After kinetic examination of serotonin adsorption, the effects of different solvents, $\mathrm{pH}$, temperature and concentration on adsorption were investigated. Selectivity and repeatability studies were investigated with these polymers.
Serotonin adsorption of MIP-EGDMA was examined for $250 \mathrm{~min}$ at $298 \mathrm{~K}$ to choose the optimum adsorption time which was found to be $2 \mathrm{~h}$.

To determine the most suitable solvent for MIPs the adsorption studies were performed using different solvents (Fig. 7). The amount of adsorbed serotonin was calculated from Eq. (1). The differences between MIPs and NIPs at pH 7.4 were 54, 78.4 and 42.12 for EGDMA, BUT and TMT, respectively [26].

Especially NIP virtually did not perform any adsorption in Triton X100. The difference between MIPs and NIPs was quite low in $\mathrm{NaCl}, \mathrm{DMSO}$, and water. The polymer interacted with these solvents but the adsorption was low. The binding with high ionic strength is weakened. Adsorption capacity decreases due to electrostatic interaction between polymer and serotonin as ionic strength increases.

Serotonin molecules were adsorbed by MIPs better than NIPs (Fig. 7). Cavities of MIPs, which are formed after serotonin removal, show a complementary feature fitting to the geometry and size of the target. However, NIPs have not cavity specific for serotonin. Thus the adsorption occurred by holding on random areas. It was expected that MIPs, which have gained memory feature by imprinting serotonin, would adsorb more substance than NIPs, which do not possess this feature. Considering polymers prepared using various cross-linkers, the highest difference between MIPs and NIPs was found for BUT. 


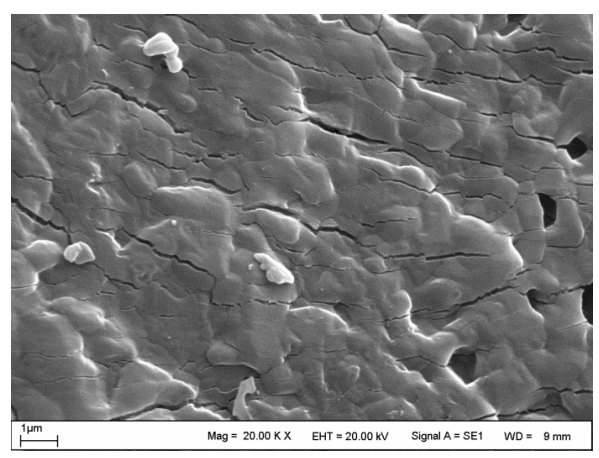

Serotonin

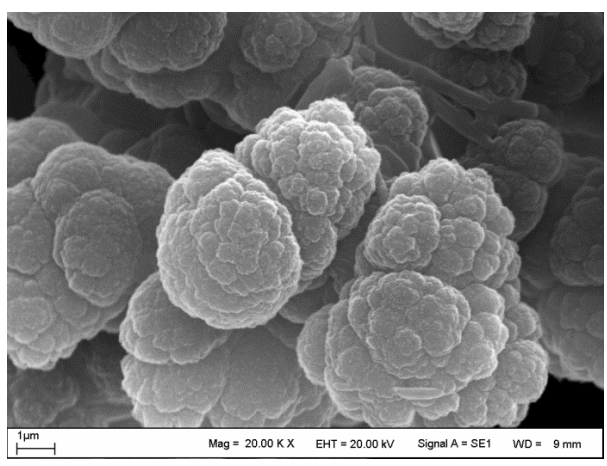

MIP-EGDMA

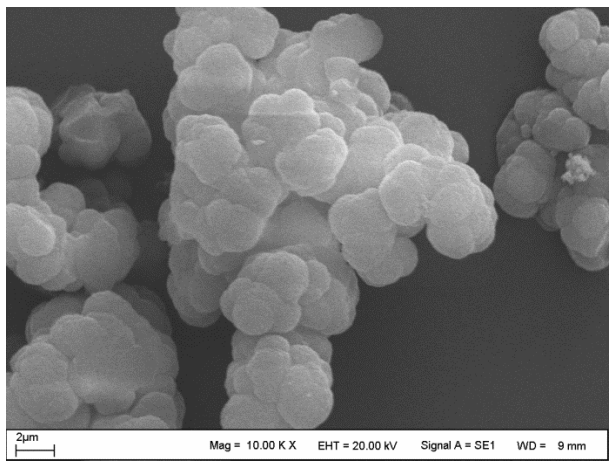

NIP-EGDMA

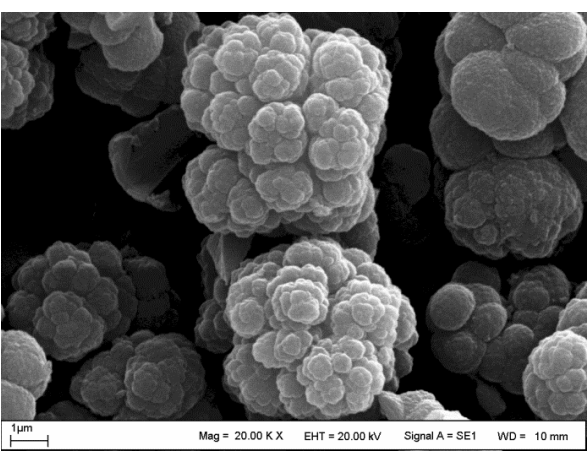

MIP-EGDMA-R

Fig. 4. SEM images of cross-linked polymer with EGDMA

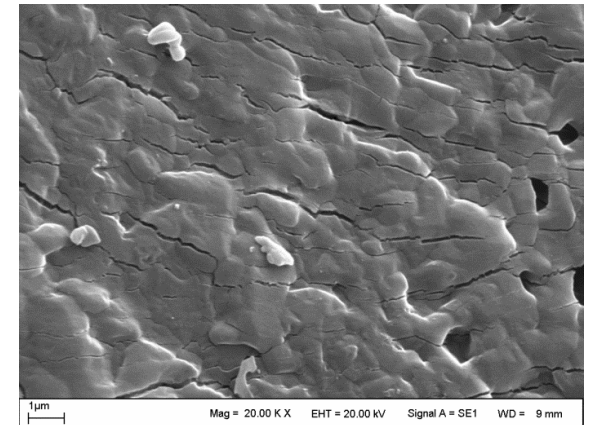

Serotonin

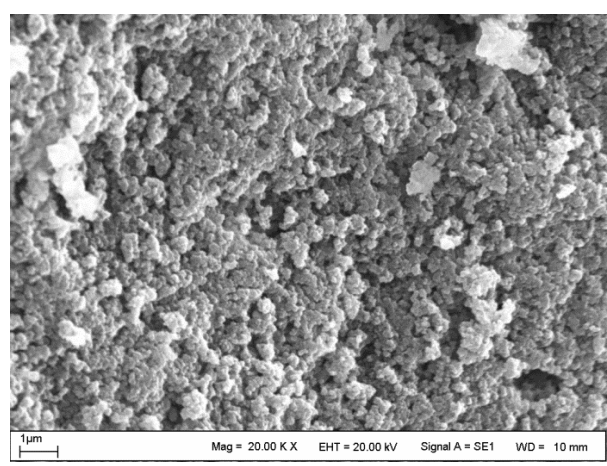

MIP-BUT

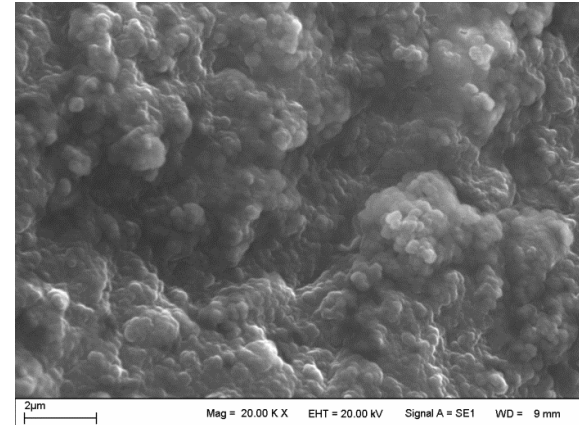

NIP-BUT

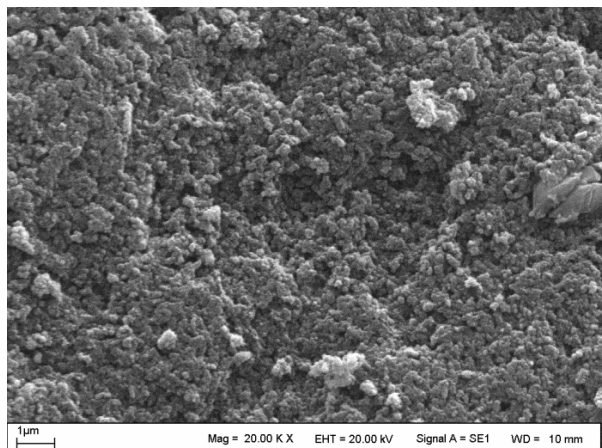

MIP-BUT-R

Fig. 5. SEM images of cross-linked polymer with BUT 


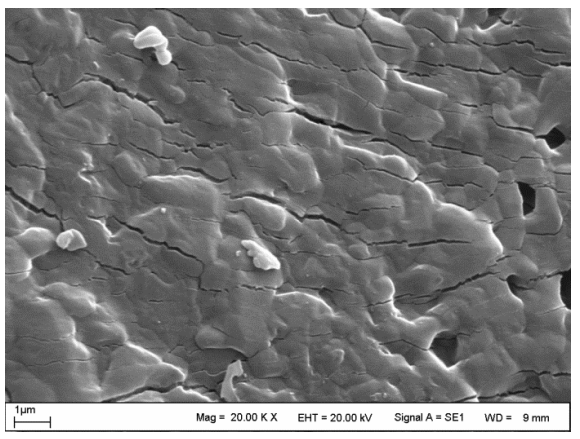

Serotonin

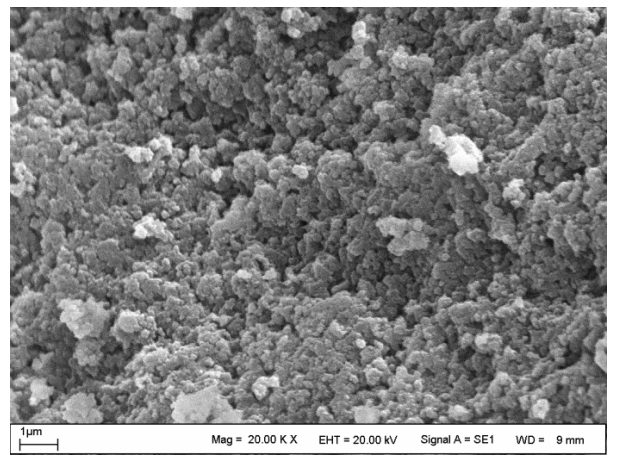

MIP-TMT

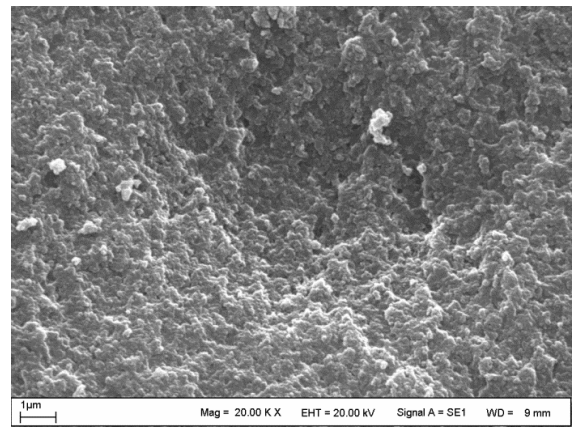

NIP-TMT

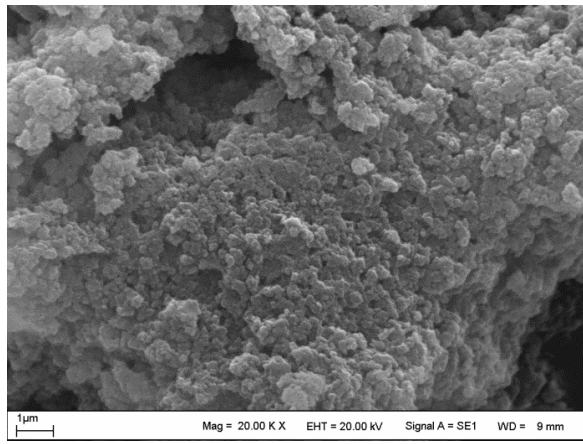

MIP TMT-R

Fig. 6. SEM images of cross-linked polymer with TMT

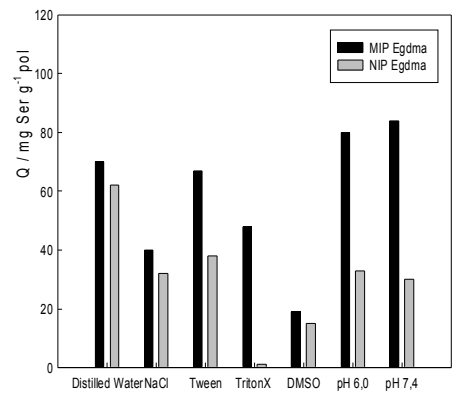

EGDMA

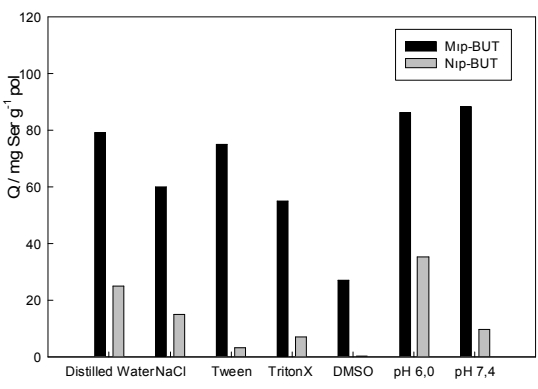

BUT

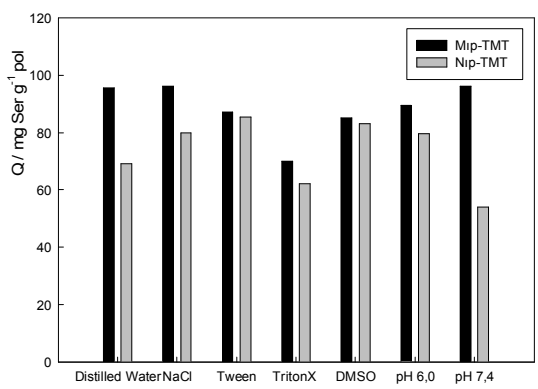

TMT

Fig. 7. Serotonin adsorption depending on different cross-linkers

It is known that the amount of substrate adsorbed by the polymers containing acidic or basic groups is changed with the change of $\mathrm{pH}$. To reveal this effect, adsorption capacity of the solutions with different $\mathrm{pH}$ has been examined. However, it was observed that serotonin was disintegrated and a new colorful structure appeared in the acidic area below pH 4.8 and in the basic area above $\mathrm{pH} 9$, thus no test could be performed at this area [27]. Serotonin molecule adsorbtion changes with $\mathrm{pH}$ and the amount of adsorbed serotonin increases as $\mathrm{pH}$ level increases. The $\mathrm{pKa}$ values of serotonin aliphatic amino group and aromatic hydroxyl group are respectively 9.8 and 10.73 [28]. When $\mathrm{pH}<\mathrm{pKa}$, serotonin molecule is in the form of conformation I. It means that below $\mathrm{pH} 9$, serotonin molecule is positively charged. When $\mathrm{pH}>\mathrm{pKa}$, the serotonin molecule switches to conformation II and becomes negatively charged. Due to the change of conformation serotonin gets colored at $\mathrm{pH} 9$ [20]. On the other hand, the polymer has more acidic $\mathrm{COOH}$ groups, thus ionization will increase as $\mathrm{pH}$ increases, the attraction between the polymer and positively charged serotonin molecule will increase due to the electrostatic effect, consequently adsorption will increase. $\mathrm{pKa}$ of the methacrylic acid used as the monomer was 4.8. For the following studies, $\mathrm{pH}$ value was set as 7.4, which is above 4.8 and below 9.8. The amount of adsorbed serotonin solutions at different $\mathrm{pH}$ levels are represented in Fig. 8. 


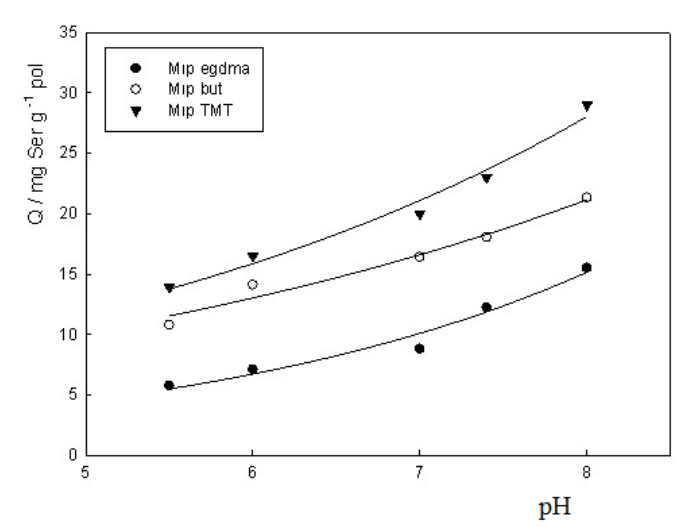

Fig. 8. The effect of $\mathrm{pH}$ on serotonin adsorbed amount

The amount of adsorbed serotonin did not change in the investigated temperature range.

The equilibrium concentration of the solutions was determined. For each concentration, equilibrium concentration of the solute $\left(C_{B}\right)$ in the adsorbent was calculated by using initial $\left(C_{T}\right)$ and balance $\left(C_{D}\right)$ concentrations and from this value the amount of the adsorbed substance was found using Eq. (3):

$$
q=\frac{C_{B} \cdot V}{m}
$$

where $q$ is the amount of serotonin adsorbed onto polymers; $V$ is the volume of solution, $1 ; m$ is the mass of the polymers, $\mathrm{g} ; C_{B}$ is the equilibrium concentration of serotonin in the adsorbent, $\mathrm{mg} / \mathrm{l}$

Isotherm curves obtained by the plotting of adsorbed amount $(Q)$ versus the equilibrium concentration are presented in Fig. 9.

Regarding the serotonin molecules adsorption isotherms of the polymers cross-linked to EGDMA, it can be said that according to the classification of Giles' adsorption isotherms, MIP-EGDMA and NIP-EGDMA are similar to L4 type; MIP-BUT and NIP-BUT are similar to L2 type; MIP-TMT and NIP-TMT are similar to L4 type [29, 30].

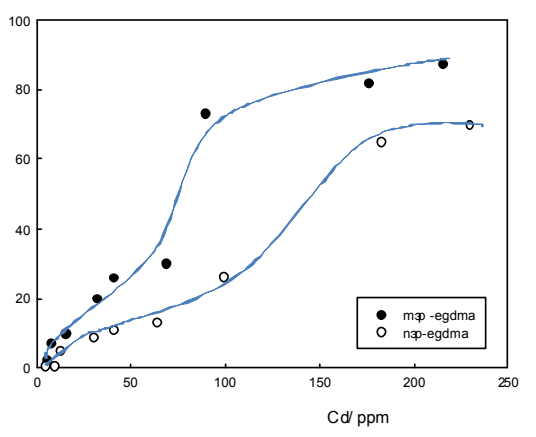

EGDMA

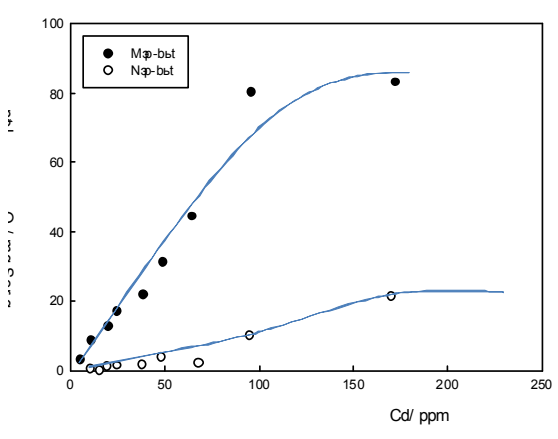

BUT
Langmuir equation is $r=\frac{n K C}{1+K C}$ and the linear form of Langmuir equation is $\frac{C}{Q}=\frac{1}{n K}+\frac{C}{n}$.

The binding constants of polymers are calculated using the above equation.

According to the classification of Giles' adsorption isotherms, the most characteristics feature of $\mathrm{L}$ type curves is an adsorbance which has strong intermolecular interaction with an adsorbate. A strong interaction between the adsorptive type and the adsorbed one is established by occurred memory effect via imprinting processes. It was observed that adsorption type is not changed with changing cross-linker. From the adsorption isotherms, $K_{i}$ (an initial binding constant), $K$ (an equilibrium binding constant), $n$ (a monolayer coating) and $\theta$ (a maximum yield rate) were calculated. The received values are represented in Table 3.

$K$ and $K_{i}$ values of MIPs are higher compared to those of NIPs and the highest $K_{i}$ value was observed for MIP-TMT. These results show that MIP samples adsorb serotonin more than NIP ones. The $n$ values are shown single layer capacity of the polymers. Moreover, MIPs perform more adsorption compared to NIPs. The values of $\theta$ show maximum yield rate. These values were less than one, which means that the layer was not fully covered and there were empty areas on the polymer where serotonin could be held. The highest adsorption was found for MIP-TMT.

The values in Table 4 show that the investigated process was physical adsorption, which is an exothermic process. Thus $\Delta G$ is negative. Negative $\Delta H$ implied that the adsorption is physical. On the other hand, positive $\Delta S$ value indicates the presence of hydrophobic interactions [31].

The results of MIP adsorption concerning selectivity are represented in Fig. 10 and Table 5. For each of cross-linkers the selectivity was found and its value decreases in the series: serotonin (Ser) $>$ homovanillic acid $(\mathrm{Hmv})>$ adrenalin $(\mathrm{Ad})$. The highest value was found for MIP-TMT.

Fig. 9. Curves of serotonin adsorption

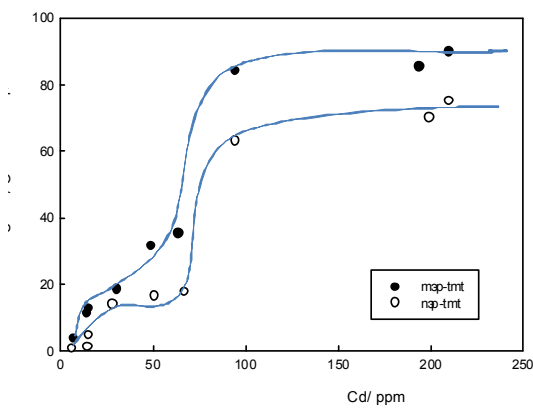

TMT 
The binding constants of polymers

\begin{tabular}{|c|c|c|c|c|}
\hline Polymer & $K_{i} \cdot 10^{3}, 1 / \mathrm{mol}$ & $K, 1 / \mathrm{mol}$ & $n \cdot 10^{3}$ & $\theta$ \\
\hline MIP-EGDMA & 10.4 & 2.1 & 5.0 & 0.7 \\
\hline NIP-EGDMA & 10.3 & 1.2 & 8.5 & 0.5 \\
\hline MIP-BUT & 28.5 & 5.7 & 5.0 & 0.8 \\
\hline NIP-BUT & 19.7 & 1.1 & 18.6 & 0.2 \\
\hline MIP-TMT & 931.7 & 169.0 & 5.5 & 0.9 \\
\hline NIP-TMT & 279.3 & 29.3 & 9.5 & 0.6 \\
\hline
\end{tabular}

Table 4

Thermodynamic parameters of polymers

\begin{tabular}{|c|c|c|c|}
\hline Polymer & $\Delta G, \mathrm{~J} / \mathrm{mol}$ & $\Delta H, \mathrm{~kJ} / \mathrm{mol}$ & $\Delta S, \mathrm{~J} / \mathrm{mol} \cdot \mathrm{K}$ \\
\hline MIP-EGDMA & -1812 & -1.6 & 6.1 \\
\hline NIP-EGDMA & -472 & -1.6 & 1.6 \\
\hline MIP-BUT & -4316 & -0.9 & 0.5 \\
\hline NIP-BUT & -144 & -1.2 & 42.6 \\
\hline MIP-TMT & -12709 & -0.7 & 28.1 \\
\hline NIP-TMT & -8368 & -1.4 & \\
\hline
\end{tabular}

Table 5

The selectivity of the target molecule

\begin{tabular}{|c|c|c|c|}
\hline Cross-linker & $Q_{\text {Ser, }} \%$ & $Q_{\text {Ad }}, \%$ & $Q_{\text {Hmv }}, \%$ \\
\hline EGDMA & 86 & 31 & 64 \\
\hline BUT & 93 & 42 & 67 \\
\hline TMT & 100 & 50 & 68 \\
\hline
\end{tabular}

Table 6

Repeatability of prepared MIPs for serotonin adsorption

\begin{tabular}{|c|c|c|c|c|c|}
\hline \multirow{2}{*}{ Cross-linker } & \multicolumn{5}{|c|}{ The number of reuse } \\
\cline { 2 - 6 } & 1 & 2 & 3 & 4 & 78 \\
\hline$Q_{\text {EGDMA }} \%$ & 84 & 81 & 80 & 77 \\
\hline$Q_{\text {BUT }} \%$ & 88 & 85 & 83.5 & 83 & 82.5 \\
\hline$Q_{\mathrm{TMT}, \%}$ & 96 & 95 & 94.7 & 92 & 90 \\
\hline
\end{tabular}

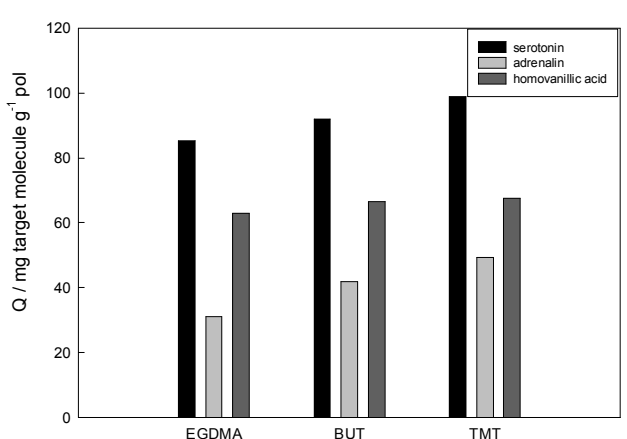

Fig. 10. Selectivity of polymers

After adsorption, in order to remove serotonin molecule bounded to the polymers, the solution was washed four times with $\mathrm{MeOH}: \mathrm{AcA}$ (4:1) and twice with $250 \mathrm{ml}$ of distilled water. Adsorption-desorption processes were repeated five times. Repeatability values (\% RE) calculated from Eq. (2) are given in Table 6.

As the result of adsorption-desorption processes, it was observed that the memory effect and structural integrity of the polymers were maintained.

\section{Conclusions}

Imprinted (MIPs) and non-printed (NIPs) polymers were formed by using acrylamide, methacrylamide and acrylic acid monomers with EGDMA, BUT, TMT crosslinkers. So, groups suitable for non-covalent interactions in the imprint of serotonin were obtained. Characterization was done using FTIR, TGA, DSC and SEM. FTIR analysis of MIP and NIP samples showed that serotonin was imprinted into the polymer and it was removed after the washing process. TGA showed that prepared polymers give multistep thermal decomposition reaction. The results of DSC analysis showed that the polymers maintain their hard and glassy structures up to $333 \mathrm{~K}$ and the sequence of glass transition temperature is MIPTMT $>$ MIP-BUT $>$ MIP-EGDMA. The changes in the MIP polymer matrix were confirmed by SEM analysis. There are significant differences between MIPs and NIPs. The images of NIPs and washed MIPs are similar.

Adsorption studies show that MIPs are better adsorptive than NIPs for all solvents. The sequence of 
adsorption is MIP-TMT $>$ MIP-BUT $>$ MIP-EGDMA. The polymer with the highest MIP/NIP difference was found to be MIP-BUT. The highest adsorption and the MIP/NIP difference were observed at $\mathrm{pH}$ 7.4. It was found that the temperature has no significant effect on adsorption. From the examination of the concentration effect on the adsorption, it was found that serotonin adsorption is L-type according to the classification of Giles' adsorption isotherms. The interaction between serotonin and polymer is very high. The binding parameters of these isotherms showed that MIPs adsorbed more serotonin than NIPs. Thermodynamic parameters found in the adsorption showed that the adsorption is a physical adsorption. Tests conducted with adrenalin and homovanillic acid which are similar to serotonin structure, showed that MIP samples are highly selective for serotonin. As the result of adsorption-desorption processes, repeated five times, it was observed that memory effect and structural integrity of the polymers were maintained.

Consequently, MIPs synthesized in this study, are the materials with improved adsorption capacity, effectiveness and selectivity, which can be reused again and again. The most distinctive feature of these polymeric materials from other polymers is their selectivity towards a specific type.

\section{Acknowledgements}

The authors gratefully acknowledge the financial support provided by the Cumhuriyet University Research Fund through Project F-310.

\section{References}

[1] Yola M., Atar N.: Appl. Surf. Sci., 2018, 458, 648. https://doi.org/10.1016/j.apsusc.2018.07.142

[2] Mathews C., van Holde K.: Biochemistry: The Benjamin/Cummings Publ. Co., Redwood City, California 1990.

[3] Sengupta B., Chaudhuri S., Banerjee A., Sengupta P.: Chem.

Biodivers., 2004, 1, 868. https://doi.org/10.1002/cbdv.200490069

[4] Suedee R., Seechammanturakit V., Suksuwan A., Canyuk B.: Int. J. Mol. Sci., 2008, 9, 2333. https://doi.org/10.3390/ijms9122333

[5] Patra S., Roy E., Madhuri R., Sharma P.: Anal. Chim. Acta, 2016, 918, 77. https://doi.org/10.1016/j.aca.2016.02.046

[6] Yan H., Row H.: Int. J. Mol. Sci., 2006, 7, 155. https://doi.org/10.3390/i7050155

[7] JeCho S., Noh H., Won M. et al.: Biosens. Bioelectron., 2018, 99, 471. https://doi.org/10.1016/j.bios.2017.08.022

[8] Hawkins D., Stevenson D., Reddy S.: Anal. Chim. Acta, 2005, 542, 61. https://doi.org/10.1016/j.aca.2005.01.052

[9] Ayankojo A., Reut J., Öpik A. et al.: Proceed. Estonian Acad. Sci., 2018, 67, 138. https://doi.org/10.3176/proc.2018.2.04

[10] Gálvez A., Mayorga-Matinez C., Parolo C. et al.: Electrochem. Commun., 2017, 82, 6. https://doi.org/10.1016/j.elecom.2017.07.007

[11] O’Mahony J., Molinelli A., Nolan K. et al.: Biosens. Bioelectron., 2005, 21, 1383. https://doi.org/10.1016/j.bios.2005.05.015

[12] Vazquez M., Spivak D.: J. Polym. Sci., 2004, 42, 3668.

https://doi.org/10.1002/pola.20186
[13] Takeuchi T., Haginaka J.: J. Chromatogr. B, 1999, 728, 1. https://doi.org/10.1016/S0378-4347(99)00057-2

[14] Tooth B., Pap T., Horvath V., Horvai G.: Anal. Chim. Acta, 2007, 591, 17. https://doi.org/10.1016/j.aca.2007.01.016

[15] Peeters M., Troost F., Van Grinsven B., et al.: Sensor. Actuat. BChem., 2012, 172, 602. https://doi.org/10.1016/j.snb.2012.05.040

[16] Turiel E., Esteban A.: Anal. Chim. Acta, 2010, 668, 87. https://doi.org/10.1016/j.aca.2010.04.019

[17] Urban J., Jandera P., Schoenmakers P.: J. Chromatogr. A, 2007, 1150, 279. https://doi.org/10.1016/j.chroma.2006.09.065

[18] Wulff G., Poll H.: Macromol. Chem. Phys., 1997, 188, 741. https://doi.org/10.1002/macp.1987.021880408

[19] Okutucu B.,Telefoncu A.: Talanta, 2008, 76, 1153. https://doi.org/10.1016/j.talanta.2008.05.033

[20] Chattopathyay A., Rukmini R., Mukherjee S.: Biophys. J., 1996, 71, 1952. https://doi.org/10.1016/S0006-3495(96)79393-1

[21] Ewing G.: Instrumental Methods of Chemical Analysis, 4.edn. McGraw-Hill,Tokyo 1975.

[22] Bayari S., Ide S.: Spectrochim. Acta A, 2003, 59, 1255.

https://doi.org/10.1016/S1386-1425(02)00308-6

[23] Lagutschenkov A., Langer J., Berden G. et al.: J. Phys. Chem. A, 2010, 114, 13268. https://doi.org/10.1021/jp109337a

[24] Peniche C., Argüelles-Monal W., Davidenko N. et al.: Biomater., 1999, 20, 1869. https://doi.org/10.1016/S0142-9612(99)00048-4

[25] Işikver Y., Saraydin D.: Polym. Eng. Sci., 2015, 55, 843. https://doi.org/10.1002/pen.23950

[26] Barati A., Kazemi E., Dadfarnia S., Shabani A.: JIEC, 2017, 46, 212. [27] Okutucu B.,Önal S.: Talanta, 2011, 87, 74.

https://doi.org/10.1016/j.talanta.2011.09.043

[28] Rudnick G., Kirk K., Fishkes H., Schuldiner S.: J. Biolog. Chem., 1989, 264, 14865.

[29] Giles C., Macewan T., Nakhwa S., Smith D.: Journal of Chemical Society, 1960, 3973. https://doi.org/10.1039/jr9600003973

[30] Işikver Y.: Fibers and Polymers, 2017, 18, 2070.

https://doi.org/10.1007/s12221-017-7215-7

[31] Saraydin D., Karadağ E.: Tr. J. Chem., 1996, 20, 234.

Received: July 22, 2018 / Revised: December 12, 2018 / Accepted: February 28, 2019

\section{ОДЕРЖАННЯ ТА ХАРАКТЕРИСТИКА ПОЛІМЕРІВ 3 "МОЛЕКУЛЯРНИМИ \\ ВІДТИСКАМИ" ДЛЯ СЕЛЕКТИВНОГО РОЗПІЗНАВАННЯ СЕРОТОНІНУ}

\begin{abstract}
Анотація. Одержсано полімери «з молекулярними відтисками» (молекулярно імпринтовані полімери, МІП) для високоселективного розпізнавання серотоніну. Як мономери для одержання МІП використано акриламід, метакрилову кислоту та метакриламид. Проведено полімеризацію функиіональних мономерів з диметакрилатом етиленгліколю, діакрилатом 1,4бутандіолу $i$ триметилпропантриакрилатом 3 серотоніном. Видалення серотоніну з МІП проводили за допомогою суміші метанол/очтова кислота (4:1). Синтезовано неімпринтовані полімери (НІП) без серотоніну. Одержані полімери досліджено за допомогою методів Фур 'є-спектроскопії, диферениійно скануючоі калориметрії, термогравіметричного аналізу та скануючої електронної мікроскопії. Встановлено вплив температури, рН $i$ концентрації на адсорбиію серотоніну. Визначено значення селективності та можливість повторного використання.
\end{abstract}

Ключові слова: акриламід, метакрилова кислота, метакриламід, молекулярно-імпринтовані полімери, серотонін. 